\title{
Transformational Leadership Style, Psychological Empowerment and Job Satisfaction in Greek $\mathrm{Mu}$ - nicipal Sport Organizations
}

\author{
Lefkothea Tsevairidou ${ }^{1}$, Ourania Matsouka ${ }^{1}$, Efstratia Tsitskari ${ }^{1}$, Vassilios Gourgoulis ${ }^{1}$ and George \\ Kosta ${ }^{1}$
}

'Democritus University of Thrace, Department of Physical Education and Sport Science, Komotini, Greece

\begin{abstract}
The aim of the present research was to examine the effects/correlations of transformational leadership style on employees' psychological empowerment in the context of Greek municipal sport organizations. Moreover, the second aim of the present study was to examine the correlation of employees' psychological empowerment on their job satisfaction in the same context of Greek municipal sport organizations. The sample of the research constituted of 30 managers and 247 employees of Greek municipal sport organizations, of Eastern Macedonia and Thrace, of Western Macedonia and of Central Macedonia. In an effort to investigate the specific concern, the managers completed the multifactor leadership questionnaire of Bass and Avolio (1997), while the employees completed the psychological empowerment instrument of Spreitzer (1995) and Minnesota Satisfaction Questionnaire (MSQ). SPSS 20 was used for the statistical data analysis. More specifically, regression analysis and Pearson's rank correlation was used for the variables that satisfied the affair of regularity, while for those variables that were not satisfied the affair of regularity was used non parametric Spearman's rank correlation coefficient. The results showed that self-determination, the dimension of psychological empowerment, had strong positive correlation with idealized influence attributes (IIA) $(r=0.492 ; p=0.007)$, and strong negative correlation with idealized influence behavior (IIB) $(r=-0.421 ; p=0.023)$ of transformational leadership style. Also, the study found significant positive correlation on psychological's empowerment dimensions with all job satisfaction's dimensions. Implications and directions for future research are discussed.

Key words: transformational style, meaning, self-determination, impact, competence, extrinsic satisfaction, intrinsic satisfaction
\end{abstract}

\section{Introduction}

Transformational leadership consists of five dimensions which are enough for the leaders to impel their followers overcome any personal interests and, against all odds, be more effective: a) idealized influence attributed, (IIA) b) idealized influence behavior, (IIB) c) inspirational motivation, (IM) d) intellectual stimulation (IS) and e) individualized consideration (IC).

The idealized influence attributed (charisma) is referred to those talented and gifted leaders who act as role models to their followers and as a result, they gain respect, trust and admiration by them. The idealized influence behavior refers to the charismatic actions of the leader, whereby individuals transcend their self-interest for the sake of the organization and develop a collective sense of mission and purpose. This dimension broadens the traditional leadership role into that of a 'manager of meaning. The inspirational motivation is referred to those leaders who inspire and impel their followers so as to succeed high-flying goals which have been difficult to be materialized. The intellectual stimulation is referred to the

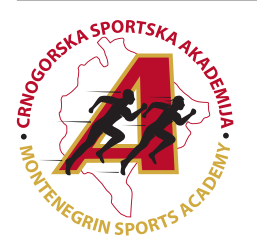

Correspondence: 
awakening and directions of the followers, the awareness and the management of difficult situations they may face, with creative and free-wheeling thought, using their imagination and innovative methods. The individualized consideration is referred to the leaders who provide socio-emotional support, tailored to their followers' needs, and at the same time they strengthen and evolve them (Antonakis, Avolio, \& Sivasubramaniam, 2003).

Empowerment of human resources covers needs, culture and the structure of each organization separately, because it constitutes one of the most fundamental elements of administrative and organizational effectiveness which is strengthened when power and control are distributed in the organization (Ergeneli, Saglam, \& Metin, 2007; Faulkner \& Laschinger, 2008).

Empowerment has been empirically studied from two different perspectives. The first perspective is Structural Empowerment, which is reported in the transfer of more power an initiative to the employees in the workforce. The second perspective is Psychological Empowerment. For Spreitzer (1995a), Thomas and Velthouse (1990), the psychological empowerment is a complicated and cognitive psychological dimension, which is mostly connected with self-confidence and emotions of the subordinated rather than the specific managerial practices that related to the structures and policies which the workforce is enforced through them (Menon, 1999). It is also specified by four cognitive dimensions: a) meaning, b) competence, c) self-determination, and d) impact. Meaning is referred to the matching of the work-role demands with the perceptions, views, values, attitudes and standards of the employer (Spreitzer, 1995). Competence is related to the employer's self confidence that he is productive enough (Thomas \& Velthouse, 1990). Self-determination is referred to the variety of options upon the tasks that an employer feels he/she has throughout his duties. Impact is defined as the belief of the employer that he/she holds sway over the functions and procedures of an organization as well as the tactical, administrative and operational results of it (Spreitzer, 1995b).

The significance of empowerment is derived from its impact on several factors that are related to organizational success, particularly the human factor. For instance, empowerment has proved to be positively influencing employees as it was linked in many studies with increase in employee job satisfaction and reduce in employee turnover (Cai \& Zhou, 2009; Chang, Shih, \& Lin, 2010; Manojlovich \& Spence Laschinger, 2002) increasing performance quality (Donahue, Piazza, Griffin, Dykes, \& Fitzpatrick, 2008; Spence Laschinger, 2008), increasing organizational commitment (Chang et al., 2010; Manojlovich \& Spence Laschinger, 2002), and employee loyalty (Chang et al., 2010), and reducing employees' burnout.

The most popular definition of job satisfaction was supplied by Locke (1976), who defined it as “...a pleasurable or positive emotional state resulting from the appraisal of one's job or job experiences" (p. 1304). According to Locke (1976), the dimensions of job satisfaction are analyzed to a) job, b) salary, c) promotions, d) recognition, e) profits, f) conditions of work, g) supervision, h) colleagues i) leadership and management.

The main objective of the current research was to examine the effect/correlation of transformational managers' style of Greek municipal sport organizations on the psychological empowerment of their employees and, to examine the correlation between the dimensions of employees' psychological empowerment on their job satisfaction.

\section{Methods}

Thirty managers and their 247 employees, permanent and contract fitness instructors, of Greek municipal sport organizations of East Macedonia and Thrace, West Macedonia and Central Macedonia, took part at the study in question. However, one manager of them was excluded from the further analysis while his employees were not replied to the questionnaires, which were given to them. Afterwards, 247 employees were grouping depending on their organization and match to their manager.

The a) Multifactor leadership questionnaire (M.L.Q) of Bass and Avolio (1997), given to the sports managers, consists of 45 questions, 5 scaled Likert, closed-questions of high validity and credibility for all the aforementioned dimensions (.91 to .94) b) Psychological Empowerment scale (Spreitzer, 1995; 1995a) consists of 12 questions, seven scaled Likert, closed-questions, the validity of the dimensions range approximately to .80, and c) Minnesota Satisfaction Questionnaire (MSQ) (Weiss et al., 1967) consists of 20 questions, five scaled Likert, closed -questions, the validity of the dimensions range approximately to .70 to .80 , given to the employees.

The collection of data for the specific project included two phases: a) the pilot research and b) the main research. The questionnaires that were used, for that study, were translated from English to Greek and inversely. The pilot research is based on the answers that were given by 25 individuals with the purpose of testing the reliability and validity of the questionnaires. Afterwards, some slight necessary improvements took place.

The distribution of the questionnaires was a part of the main research, which was completed through e-mails, towards the persons in charge of the sports organizations. Those individuals, with whom retained a regular telephone contact, participated in the mass athletic program at the districts of East Macedonia and Thrace, West Macedonia and Central Macedonia.

The first part of the questionnaire referred to the demographic features of the respondents such as the sex, age, location, family status, education, monthly earnings, experience and years of employment at the organization. Filling out the questionnaire for every dimension was the second part of the procedure.

\section{Results}

The analysis of data was carried out with the help of SPSS 20. Firstly the factors of the questionnaires were calculated as the average of the responses to the corresponding questions in each factor. Then, the factors were checked towards the test for Normality (Razali, Wah, \& Sciences, 2011; Shapiro \& Wilk, 1965). For the analysis of the results, $\mathrm{p}=0.05$ was defined as the level of statistical significance. For the investigation of the first statistical hypothesis regarding the effect/correlation of the transformational style of leadership upon the dimensions of psychological empowerment Linear regression was applied for the dimensions that fulfilled the Test of Normality, whereas, Spearman correlation was applied for non-parametrical analysis about the dimensions that couldn't fulfill the Test of Normality. The results proved that only self-determination of psychological empowerment had a major positive correlation with the idealized influence attributed (IIA) of the transformational style $(\mathrm{r}=0.492 ; \mathrm{p}=0.007)$ and considerable negative correlation with the idealized influence behavior (IIB) of the same style $(\mathrm{r}=-0.421 ; \mathrm{p}=0.023$; Table 1$)$. 
Table 1. Results of the Correlation/Effect of Transformational Leadership towards the Subordinates' Psychological Empowerment

\begin{tabular}{|c|c|c|c|c|c|c|}
\hline & IIA & IIB & IM & IS & IC & $\begin{array}{c}\text { Total } \\
\text { transfor. style }\end{array}$ \\
\hline \multirow{2}{*}{ Meaning } & $r=0.131$ & $r=0.054$ & $r=0.240$ & $r=0.035$ & \multirow{4}{*}{$\begin{array}{c}F(1,27)=0.079 \\
p=0.781 \\
R^{2}=0.3 \% \\
r=0.229 \\
p=0.233\end{array}$} & \multirow{4}{*}{$\begin{array}{c}F(1,27)=0.032 \\
p=0.858 \\
R^{2}=0.1 \% \\
r=0.067 ; \\
p=0.728\end{array}$} \\
\hline & $p=0.497$ & $p=0.782$ & $p=0.209$ & $p=0.857$ & & \\
\hline \multirow{2}{*}{ Competence } & $r=0.006$ & $r=0.029$ & $r=0.016$ & $r=-0.119$ & & \\
\hline & $p=0.976$ & $p=0.881$ & $p=0.934$ & $\mathrm{p}=0.537$ & & \\
\hline Determination & & & & & \multirow{2}{*}{$\begin{array}{c}F(1,27)=2.376 ; \\
p=0.135 ; \\
R^{2}=8.1 \%\end{array}$} & \multirow{6}{*}{$\begin{array}{c}F(1,27)=5.702 ; \\
p=0.024^{*} \\
R^{2}=17.4 \% \\
F(1,27)=0.149 ; \\
p=0.702 ; \\
R^{2}=0.5 \% \\
F(1,27)=0.910 ; \\
p=0.349 ; \\
R^{2}=3.3 \%\end{array}$} \\
\hline & $p=0.007^{*}$ & $\mathrm{p}=0.023^{*}$ & $p=0.660$ & $p=0.447$ & & \\
\hline Impact & $r=0.191^{*} ;$ & $r=-0.055$ & $r=0.065$ & $r=0.093$ & $F(1,27)=0.266$ & \\
\hline & $p=0.320$ & $p=0.776$ & $p=0.738$ & $p=0.632$ & $\begin{array}{l}p=0.610 \\
R^{2}=1.0 \%\end{array}$ & \\
\hline \multirow{2}{*}{ Psych. emp. } & $r=0.302$ & $r=-0.171$ & $r=0.011 ;$ & $r=0.091$ & \multirow{2}{*}{$\begin{array}{c}F(1,27)=0.043 \\
p=0.837 \\
R^{2}=0.2 \%\end{array}$} & \\
\hline & $p=0.112$ & $p=0.375$ & $p=0.955$ & $p=0.640$ & & \\
\hline
\end{tabular}

Legend: ${ }^{*}-\mathrm{p}<0.05$

More specifically, the more idealized influence attributed is increasing, the better self- determination is strengthened. Whereas, the more idealized influence behavior is

enhancing, the more considerable decrease is noted towards self-determination (Figures 1,2).

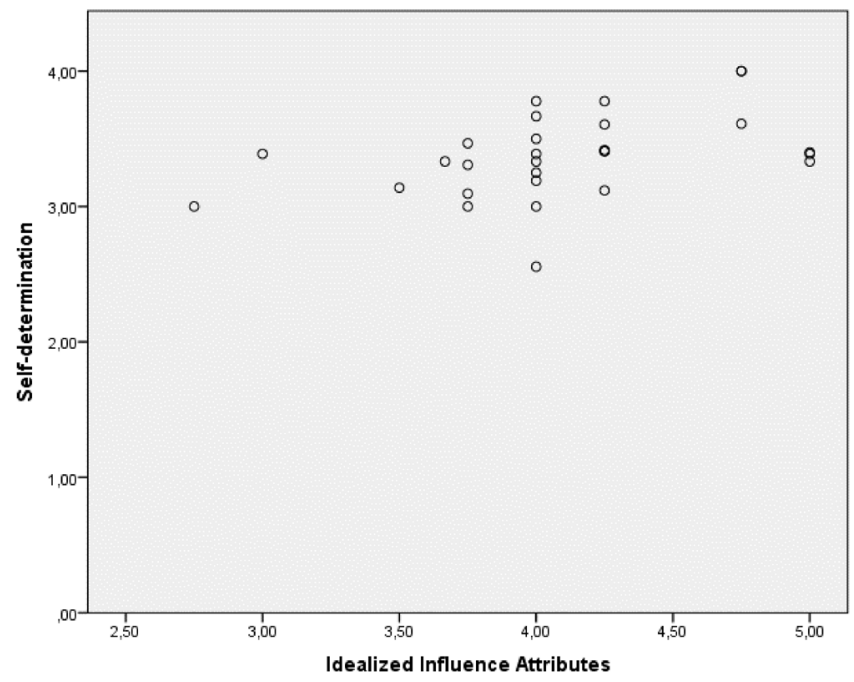

Figure 1. The factor idealized influence on attributes of the transformational leadership seems to be considerably and positively related to the subordinates' self-determination $(r=0.492, p=0.007)$.

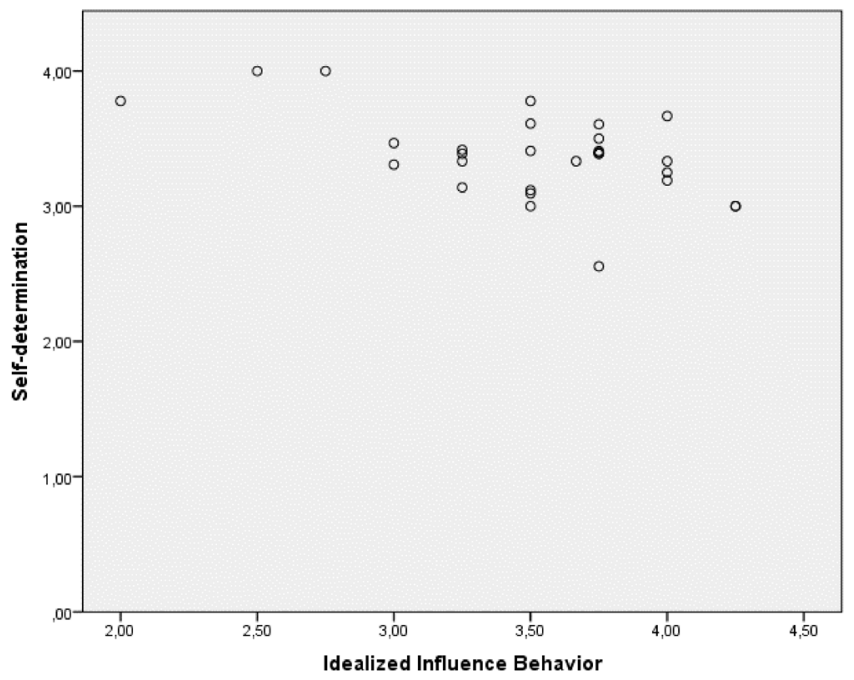

Figure 2. The factor idealized influence on behavior of the same style had a quite negative relation with self-determination $(r=-0.421, p=0.023)$ 
Furthermore, on the whole transformational leadership can $\mathrm{p}=0.024 ; \mathrm{R} 2=0.174)$ and transformational style justifies the significantly provide for self-determination $(\mathrm{F}(27,1)=5.702 ; \quad 17.4 \%$ of the subordinates' self-determination (Figure 3 ).

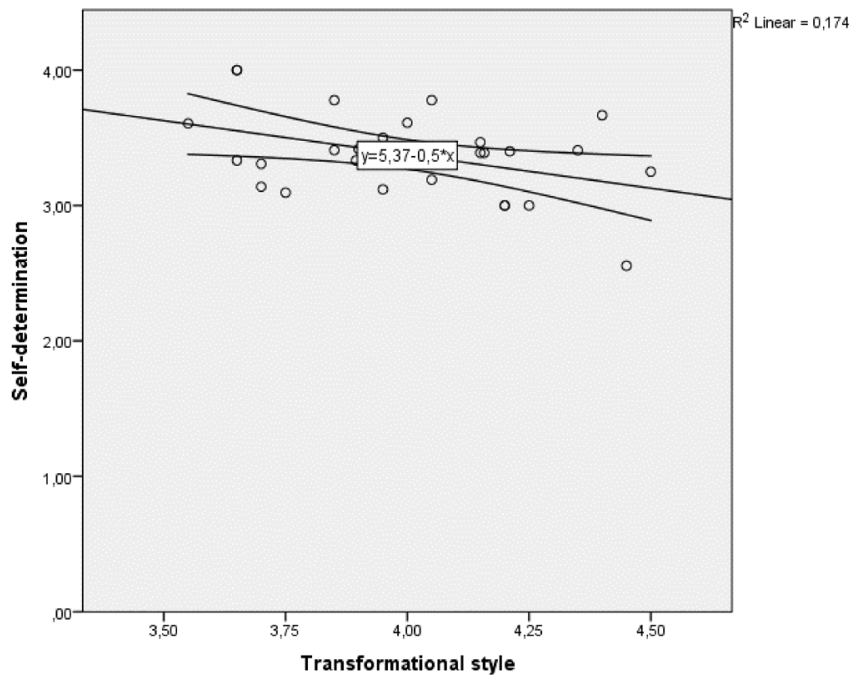

Figure 3. The transformational style seems to provide for self determination

For the investigation of the second statistical hypothesis regarding the correlation of four dimensions (meaning, competence, self- determination, and impact) of psychological empowerment upon the dimensions of job satisfaction (intrinsic, extrinsic general satisfaction) initially examined to 247 employees. Spearman correlation was applied for non- parametrical analysis because the dimensions couldn't fulfill the Test of Normality. The results proved that all dimensions of psychological empowerment (meaning, competence, self- determination, and impact) had significant positive correlation with all dimensions of job satisfaction (intrinsic, extrinsic and general satisfaction). More specifically, when each dimension of psychological empowerment (meaning, competence, self- determination, impact) is increasing each dimension of job satisfaction (intrinsic extrinsic and general satisfaction) is enhancing. Whereas, when each dimension of psychological empowerment (meaning, competence, self- determination, impact) is decreasing each dimension of job satisfaction ((intrinsic extrinsic and general satisfaction) is decreasing as well (Table 2).

Table 2. Results of the Correlation of Employees Psychological Empowerment towards Their Job Satisfaction $(\mathrm{N}=247)$

\begin{tabular}{cccccc}
\hline & Meaning & Competence & $\begin{array}{c}\text { Self - } \\
\text { determination }\end{array}$ & Impact & $\begin{array}{c}\text { Psychological } \\
\text { empowerment }\end{array}$ \\
\hline Internal & $\mathrm{r}_{\mathrm{s}}=0.497 ;$ & $\mathrm{r}_{\mathrm{s}}=0.393_{;}$ & $\mathrm{r}_{\mathrm{s}}=0.506 ;$ & $\mathrm{r}_{\mathrm{s}}=0.420 ;$ & $\mathrm{r}_{\mathrm{s}}=0.596 ;$ \\
satisfaction & $\mathrm{p}<0.001^{* *}$ & $\mathrm{p}<0.001^{* *}$ & $\mathrm{p}<0.001 * *$ & $\mathrm{p}<0.001 * *$ & $\mathrm{p}<0.001^{* *}$ \\
External & $\mathrm{r}_{\mathrm{s}}=0.304 ;$ & $\mathrm{r}_{\mathrm{s}}=0.174 ;$ & $\mathrm{r}_{\mathrm{s}}=0.199 ;$ & $\mathrm{r}_{\mathrm{s}}=0.256 ;$ & $\mathrm{r}_{\mathrm{s}}=0.324 ;$ \\
satisfaction & $\mathrm{p}<0.001^{* *}$ & $\mathrm{p}=0.006^{* *}$ & $\mathrm{p}=0.002^{* *}$ & $\mathrm{p}<0.001 * *$ & $\mathrm{p}<0.001^{* *}$ \\
General & $\mathrm{r}_{\mathrm{s}}=0.447 ;$ & $\mathrm{r}_{\mathrm{s}}=0.334 ;$ & $\mathrm{r}_{\mathrm{s}}=0.396 ;$ & $\mathrm{r}_{\mathrm{s}}=0.376 ;$ & $\mathrm{r}_{\mathrm{s}}=0.518 ;$ \\
satisfaction & $\mathrm{p}<0.001^{* *}$ & $\mathrm{p}<0.001^{* *}$ & $\mathrm{p}=0.001^{* *}$ & $\mathrm{p}<0.001$ & $\mathrm{p}<0.001^{* *}$ \\
\hline
\end{tabular}

Legend: * $-p<0.01$

Afterwards, the above correlations were examined to the sample of 29 employees, which resulted after their grouping depending on their organization and matching to their manager. In this team were not observed important correlations between dimensions of psychological empowerment and internal satisfaction (Table 3). However, statistically important

positive correlations were found between dimensions of psychological empowerment, meaning, self-determination, and total psychological empowerment with external satisfaction and general dimension. Moreover, competence of psychological empowerment was statistically positive correlated with general satisfaction (Table 3).

Table 3. Results of the Correlation of Employees Psychological Empowerment towards Their Job Satisfaction $(\mathrm{N}=29)$.

\begin{tabular}{|c|c|c|c|c|c|}
\hline & Meaning & Competence & $\begin{array}{c}\text { Self - } \\
\text { determination }\end{array}$ & Impact & $\begin{array}{l}\text { Psychological } \\
\text { empowerment }\end{array}$ \\
\hline Internal & $r=-0.069$ & $r_{s}=-0.119 ;$ & $r=0.033$ & $r=0.050$; & $r=-0.015$ \\
\hline satisfaction & $\mathrm{p}=0.723$ & $\mathrm{p}=0.537$ & $p=0.866$ & $p=0.796$ & $p=0.939$ \\
\hline $\begin{array}{c}\text { External } \\
\text { satisfaction }\end{array}$ & $\begin{array}{c}r=0.627 \\
p<0.001 * *\end{array}$ & $\begin{array}{l}r_{s}=0.354 ; \\
p=0.059\end{array}$ & $\begin{array}{c}r=0.373 \\
p=0.0047 \text { * }\end{array}$ & $\begin{array}{l}r=0.347 ; \\
p=0.065\end{array}$ & $\begin{array}{c}r=0.545 \\
p=0.002 * *\end{array}$ \\
\hline $\begin{array}{c}\text { General } \\
\text { satisfaction }\end{array}$ & $\begin{array}{c}r_{s}=0.720 \\
p<0.001 * *\end{array}$ & $\begin{array}{l}r_{s}=0.460 \\
p=0.012\end{array}$ & $\begin{array}{l}r_{s}=0.552 \\
p=0.002\end{array}$ & $\begin{array}{l}r_{s}=0.201 \\
p=0.295\end{array}$ & $\begin{array}{c}r_{s}=0.638 \\
p<0.001 * *\end{array}$ \\
\hline
\end{tabular}

Legend: ${ }^{*}-p<0.05$; $^{* *}-p<0.01$ 


\section{Discussion}

The purpose of the current study was twofold. Firstly, it was the investigation of the effect/correlation of transformational leadership style that is applied by the managers of Greek municipal sport organizations to their employee's psychological empowerment, permanent or contract fitness instructors. Secondly, it was the investigation of the correlation of employees' psychological empowerment, permanent or contract fitness instructors, to their job satisfaction.

Therefore, it must be mentioned that the results of the particular survey came up after collecting the necessary data taken from a specific number of sport organizations and not throughout the country as a whole. There was a major positive correlation of the idealized influence attributed of the transformational leadership, with the self determination of the psychological empowerment. However, statistically emerged a negative correlation of the idealized influence on behavior of the transformational leadership with the same dimension of self-determination.

More specifically, the transformational leaders, through their enthusiasm, high moral role models, rectitude and optimism, create a team spirit providing in that way meaning and challenge to the work area of their employees, enforcing their subordinates' level of self-effectiveness, trust, intention and self- determination. The main goal is the empowerment and commodity of their employees in order to achieve their objectives (Avolio, 1999; Avolio, Zhu, Koh, \& Bhatia, 2004; Bass \& Avolio, 1994; Kark, Shamir, \& Chen, 2003; Luthans \& Avolio, 2003; Walumbwa, Avolio, Luthans, May, \& Gardner, 2004).

The above founding are fortified with those of Özaralli (2003), who examined the effect of transformational leadership upon the four dimensions of the psychological empowerment, both on the industry field and the banking one in Turkey. The results indicated the significant effect of the transformational leadership upon every dimension of the psychological empowerment. Equally, Avolio et al., (2004), conducted a survey among the nurses in a public hospital of Singapore so as to investigate the role of the transformational leadership upon psychological empowerment. It is proved that the specific style of leadership improves the psychological empowerment of the workforce in hospitals and as a result it strengthens their bonds with the organization. The best intermediate factor for strengthening the dimensions of the meaning and competence of the psychological empowerment is the dimension of the idealized influence of the transformational leadership, while the best intermediate factor of boosting the dimension of self-determination is the inspirational motivation.

Also, there was positive correlation between the four dimensions of psychological empowerment and the dimensions of job satisfaction for the sample of 247 employees. Similarly, there was positive correlation between dimensions of psychological empowerment, meaning, self-determination, and total psychological empowerment with external satisfaction and general dimension for the sample of 29 employees after their grouping. Moreover, competence of psychological empowerment was positive correlated with general satisfaction for the same sample of 29 employees.

The above founding are fortified with the results of Jun kal Lee (2000), who examined the correlation of psychological empowerment upon the dimensions of job satisfaction on employees in hotels on South Korea (Hechanova, Alampay, \& Franco, 2006). Recently, Pelit, Yüksel Öztürk and Arslantürk
(2011), investigated the effect of psychological's dimensions on job satisfaction on five stars hotels employees' in Turkey. The founding show positive correlation between dimensions of psychological empowerment on job satisfaction. Equally, these finding agree with those in the aspect of health in Malaysia, where there was a strong correlation of employee's psychological empowerment with their job satisfaction (Ahmad \& Oranye, 2010; Thorlakson \& Murray, 1996; Yang, Liu, Chen, \& Pan, 2014). Such results could be attributed to the important role of psychological empowerment while it restructures the environment of the workforce and decreasing the feelings of weakness between the employees.

Overall, this study extends theory and empirical research in the domain that transformational leadership is positively associated with psychological empowerment (Avolio et al., 2004) and confirmed the significant role of psychological empowerment on job satisfaction (Hechanova et al., 2006). The results of this study provide a theoretical basis for leadership management. According to the findings, organizations should enhance their top management leadership skill in term of visionary motivating, moral modeling, charisma and individualized consideration.

Furthermore, future research should address the relationships of transformational leadership, psychological empowerment and job satisfaction as well as study these latter forms in more depth and their correlation in different aspects.

\section{Acknowledgements}

There are no acknowledgements.

\section{Conflict of Interest}

The authors declare that there are no conflicts of interest.

Received: 27 March 2019 | Accepted: 03 May 2019 | Published: 01 June 2019

\section{References}

Ahmad, N. \& Oranye, N.O. (2010). Empowerment, job satisfaction and organizational commitment: a comparative analysis of nurses working in Malaysia and England. Journal Nurse Management, 18(5), 582-591. doi: 10.1111/j.1365-2834.2010.01093.x.

Antonakis, J., Avolio, B.J., \& Sivasubramaniam, N. (2003). Context and leadership: An examination of the nine-factor full-range leadership theory using the multifactor leadership questionnaire. The Leadership Quarterly, 14(3), 261-295.

Avolio, B.J. (1999). Full leadership development. Thousand Oaks, CA:Sage.

Avolio, B.J., Zhu, W., Koh, W., \& Bhatia, P. (2004). Transformational leadership and organizational commitment: mediating role of psychological empowerment and moderating role of structural distance. Journal of Organizational Behavior, 25(8), 951-968.

Bass, B.M. \& Avolio, B.J. (2000). 'MLQ Multifactor Leadership Questionnaire Technical Report, 'Redwood City, CA: Mindgarden.

Bass, B.M. \& Avolio, B.J. (1997). Full range leadership development: Manual for the multifactor leadership questionnaire. CA, Mind Garden.

Cai, C. \& Zhou, Z. (2009). Structural empowerment, job satisfaction and turnover intention of Chinese clinical nurses. Nursing and Health Sciences, 11, 397-403.

Chang, L.C., Shih, C.H., \& Lin, S.M. (2010). The mediating role of psychological empowerment on job satisfaction and organizational commitment for school health nurses: A cross-sectional questionnaire survey. International Journal of Nursing Studies, 47(4), 427-433.

Donahue, M.O., Piazza, I.M., Griffin, M.Q., Dykes, P.C., \& Fitzpatrick, J.J. (2008). The relationship between nurses' perceptions of empowerment and patient satisfaction. Applied Nursing Research, 21, 2-7.

Ergeneli, A., Ari, G.S., \& Metin, S. (2007). Psychological empowerment and its relationship to trust in immediate managers. Journal of Business Research, 60, 41-49.

Faulkner, J. \& Laschinger, H.L. (2008). The effects of structural and psychological empowerment on perceived respect in acute care nurses. Journal of Nursing Management, 16(2), 214-221. 
Hechanova, R.M., Alampay, R.B., \& Franco, E. (2006). Psychological empowerment, job satisfaction and performance among Filipino service workers. Asian Journal of social Psychology, 9(1), 72-78.

Kark, R., Shamir, B., \& Chen, G. (2003). The two faces of transformational leadership: Empowerment and dependency. Journal of Applied Psychology, 88(2), 246-255. doi: 10.1037/0021-9010.88.2.246.

Locke, E.A. (1976). The nature and causes of job satisfaction. In M.D.Dunnette (Ed). Handbook of industrial and organizational psychology (1297-1343). Chicago: Rand McNally.

Luthans, F. \& Avolio, B. (2003). Authentic leadership: a positive development ap proach. In K. S. Cameron, J.E. Dutton, \& R.E. Quinn (Eds.), Positive organizational scholarship (241-258). San Francisco, CA: Berrett-Koehler.

Menon, S.T. (1999). Psychological Empowerment: Definition, Measurement and Validation. Canadian Journal of Behavioral Sciences, 31(3), 161-164.

Manojlovich, M. \& Spence Laschinger, H.K. (2002). The relationship of empowerment and selected personality characteristics to nursing job satisfaction. Journal of Nursing Administration, 32(11), 586-595.

Özaralli, N. (2003). Effects of Transformational Leadership on Empowerment and Team Effectiveness. Leadership \& Organization Development Journal, 24(5/6), 335-345.

Pelit, E., Yüksel Öztürk, Y., \& Arslantürk, Y. (2011). The effects of employee empowerment on employee job satisfaction: A study on hotels in Turkey. International Journal of Contemporary Hospitality Management, 23(6), 784-802. http://dx.doi.org/10.1108/09596111111153475

Razali, N.M., Wah, Y.B., \& Sciences, M. (2011). Power comparisons of Shapiro-Wilk, Kolmogorov-Smirnov, Lilliefors and Anderson-Darling tests. Journal of Statistical Modeling and Anlytics, 2(1), 21-33.

Shapiro, S.S. \& Wilk, M.B. (1965). An analysis of variance test for normality (complete samples). Biometrika, 52(3-4), 591-611. http://doi.org/10.1093/biomet/52.3-4.591.
Spence Laschinger, H.K. (2008). Effect of empowerment on professiona practice environments, work satisfaction, and patient care quality: Further testing the nursing work life model. Journal of Nursing Care Quality, 23(4), 322-330.

Spreitzer, G.M. (1995). Psychological empowerment in the workplace: dimensions, measurement and validation. The Academy of Management Review, 38(5), 1442-1465.

Spreitzer, G.M. (1995a). Psychological Empowerment in the Workplace: Dimensions, measurement, and validation. Academy of Management Journal, 38(5), 1442-1465.

Spreitzer, G.M. (1995b). An Empirical Test of a Comprehensive Model of Intrapersonal Empowerment in the Workplace. American Journal of Community Psychology, 23(5), 601-629.

Thomas, K.W. \& Velthouse, B.A. (1990). Cognitive Elements of Empowerment. An interpretive model of Intrinsic Task Motivation. The Academy of Management Review, 15(4), 666-681.

Thorlakson, A.J.H. \& Murray, R.P. (1996). An Empirical Study of Empowerment in the Workplace. Group Org Management, 21(1), 67-83.

Yang, J., Liu, Y., Chen, Y., \& Pan, X. (2014). The effect of structural empowerment and organizational commitment on Chinese nurses' job satisfaction. Appl Nurs Res, 27(3), 186-191. doi: 10.1016/j. apnr.2013.12.001

Walumbwa, F.O., Avolio, B.J., Luthans, F., May, D.R. \& Gardner, W.L. (2004) Unlocking the mask: Understanding the multiple influence of authentic leadership. Presented at the University of Nebraska Gallup Leadership Institute Authentic Leadership Confence, Omaha, NE, June.

Weiss, D.J., Dawis, R.V., England, G.W., \& Lofquist, L.H. (1967). Manual for the Minnesota Satisfaction Questionnaire. Minnesota Studies in Vocational Rehabilitation, 22. Industrial Relations Center, University of Minnesota. 